\title{
Impacts of solid waste management in Pakistan: a case study of Rawalpindi city
}

\author{
H. Nisar ${ }^{1}$, N. Ejaz ${ }^{1}$, Z. Naushad ${ }^{2}$ \& Z. Ali $^{1}$ \\ ${ }^{1}$ University of Engineering \& Technology, Taxila, Pakistan \\ ${ }^{2}$ University of Auckland, New Zealand
}

\begin{abstract}
Improper solid waste management is causing negative impacts in Pakistan. To investigate the causes Rawalpindi city was selected as a case study. The situation is becoming very complex in the city due to industrialization, urbanization and improved living standards of urban areas, as these things are the cause of drastic increase in the quantity and complexity of generated waste. From this research, it is revealed that we have two major problems due to poor solid waste management, i.e. communicable diseases and unhygienic environment. Because of high growth rate, high waste generation rate, lack of efficient management and legislation, existing solid waste management systems in the city are not working properly. The main reasons for the failure of municipal solid waste management systems are unplanned annexation of the city, extreme weather conditions, lack of public awareness/community involvement, improper resources including improper equipment and lack of funds. Failure of the municipal solid waste management system has serious environmental impacts like infectious diseases, land and air pollution, blockage of drains and water pollution in natural streams.
\end{abstract} Keywords: solid waste, Rawalpindi city, environmental Impacts, land pollution.

\section{Introduction}

Solid waste management includes all activities that seek to minimize the health, environmental and aesthetic impacts of solid wastes. Presently we are facing the problems in collection, transportation and disposal of domestic solid waste in Pakistan irrespective of the size of the city, therefore the environmental and sanitary conditions are becoming very complex and people are helpless to live with unsanitary and unhygienic conditions. Solid waste management problems 
include the consideration of all the aspects relating to solid waste and its management, either directly or indirectly. These aspects may include rate of urbanization, pattern and density of urban areas, physical composition of waste, density of waste, temperature and precipitation, scavenger's activity for recyclable separation, the capacity, adequacy and limitations of respective municipalities to manage the solid waste. Due to different life styles in communities, development authorities are not able to provide similar type of solid waste management system for different communities, therefore in Pakistan a lot of non-standard solid waste management systems are working. Collection efficiency of solid waste is also very low due to lack of storage bins and improper management system. Open dumping, open burning and un-engineered sanitary landfilling of solid waste are the disposal methods through out Pakistan. These methods of solid waste disposal are causing environmental degradation through out the country [1].

\subsection{Risks and problems associated with solid wastes in study area}

In Rawalpindi city, solid wastes are not managed properly; therefore, there are many negative impacts that may result. Some of the most important are mentioned in the following list:

- Uncollected wastes often end up in drains, causing blockages which result in flooding and unsanitary conditions in the city.

- Flies breed in some constituents of solid wastes, and flies are very effective vectors that spread disease.

- Mosquitoes breed in blocked drains and in rainwater that is retained in discarded cans, tyres and other objects. Mosquitoes spread disease, including malaria and dengue.

- Rats find shelter and food in waste dumps. Rats consume and spoil food, spread disease, damage electrical cables and other materials and inflict unpleasant bites. The open burning of waste causes air pollution; the products of combustion include dioxins which are particularly hazardous.

- Uncollected waste degrades the urban environment, discouraging efforts to keep streets and open spaces in a clean and attractive condition. Solid waste management is a clear indicator of the effectiveness of a municipal administration - if the provision of this service is inadequate large numbers of citizens (voters) are aware of it. Plastic bags are a particular aesthetic nuisance and they cause the death of grazing animals which eat them.

- Waste collection workers face particular occupational hazards, including strains from lifting, injuries from sharp objects and traffic accidents.

- Dumps of waste and abandoned vehicles block streets and other access ways.

- Dangerous items (such as broken glass, razor blades, hypodermic needles and other healthcare wastes, aerosol cans and potentially 
explosive containers and chemicals from industries) may pose risks of injury or poisoning, particularly to children and people who sort through the waste.

- Heavy refuse collection trucks cause significant damage to the surfaces of roads that were not designed for such weights.

- Waste items that are recycled without being cleaned effectively or sterilized transmit infection to later users. (Examples are bottles and medical supplies.)

- Polluted water (leachate) flowing from waste dumps and disposal sites causes serious pollution of water supplies. Chemical wastes (especially persistent organics) may be fatal or have serious effects if ingested, inhaled or touched and can cause widespread pollution of water supplies.

- Large quantities of waste that have not been placed according to good engineering practice can slip and collapse, burying and killing people.

- Waste that is treated or disposed of in unsatisfactory ways causes a severe aesthetic nuisance in terms of smell and appearance.

- Liquids and fumes, escaping from deposits of chemical wastes (perhaps formed as a result of chemical reactions between components in the wastes), have fatal or other serious effects.

- Landfill gas (which is produced by the decomposition of wastes) can be explosive if it is allowed to accumulate in confined spaces.

- Methane (one of the main components of landfill gas) is much more effective than carbon dioxide as a greenhouse gas, leading to climate change.

- Fires on disposal sites can cause major air pollution, causing illness and reducing visibility, making disposal sites dangerously unstable, causing explosions of cans, and possibly spreading to adjacent property.

- Former disposal sites provide very poor foundation support for large buildings, so buildings constructed on former sites are prone to collapse.

\subsection{Waste generation}

A study was carried out on "Data Collection for Preparation of National Study on Privatization of Solid Waste Management in Eight Selected Cities of Pakistan" during 1996. The study revealed that the rate of waste generation from all type of municipal areas varies from $0.283 \mathrm{~kg} / \mathrm{capita} /$ day to 0.613 $\mathrm{kg} / \mathrm{capita} /$ day in the selected cities from Sibi to Karachi. It shows a particular trend of waste generation wherein increase has been recorded in accordance with city's population besides its social and economic development.

\subsection{Waste collection}

Solid waste is collected through deployment of the sweepers and sanitary workers from the streets with the help of wheel borrows, by brooming through roads and streets and waste is temporarily collected in containers/dumpsites 
from where it is lifted with the help of collection vehicles and carry out to final disposal sites. Sweeping of streets and roads and lifting of solid waste to final disposal is not carried out regularly specially from the poor community areas which are mostly ignored places. Furthermore collection bins and vehicles are few in numbers and are not maintained properly, therefore large number of solid waste heaps, free access of grazing animals to dumpsites, open burning and clouds of smokes at dumpsites are visible.

In Pakistan, solid waste is mainly collected by municipal authorities and collection efficiency varies from 0 percent in rural areas to 90 percent in highincome urban areas. In remote areas, where the only means of solid waste disposal is often scavenging by people and animals, natural biodegradation and dispersion, burning at the primary point of disposal, and local self-help for disposal to informal (technically illegal) dumping sites [3].

Collection rate of solid waste ranges from $51 \%$ to $69 \%$ of the generated waste. The uncollected waste, i.e., $49 \%$ to $31 \%$ remains on streets /road corners, open spaces/plots and goes to nullahs/drains. The uncollected waste is polluting the environment and causes the blockages of drains.

\section{A case study of solid waste management in "Rawalpindi"}

The City District Government Rawalpindi, through its sanitation staff that includes sweepers, collects the waste from the city area and the household, manages the collection of solid waste from the city. The supervisory staff of Rawalpindi municipal committee includes sanitary inspectors and chief sanitary inspectors who supervise the collection and disposal of solid waste and provide guidelines to their junior staff. The places near the communal storage facilities are completely littered around. People have a tendency to throw the waste from a distance to the communal points that present a view of spilled over garbage. Collection vehicles are less in number and are not properly maintained. The numbers of actual trips made by the garbage collection vehicles are on an average 2 per day, less than the designed number i.e. 3 trips per day. City District Government has placed 200 containers in 57 wards of Rawalpindi city. Amongst them 100 containers are lifted daily. While 128 tons per day (46720 tons per year) is scavenged by the scavengers [4]. City District Government Rawalpindi had recently run a project called 'SWEEP" abbreviated for Solid Waste Environmental Enhancement Project for the city [4]. SWEEP project sponsored by UNDP aims at involving all the stake holders in participation in various activities of primary collection of municipal solid waste from the house holds to the communal bins enabling the municipality to collect, transport and dispose of the solid waste. The SWEEP project formed integral part of the overall SWM program. This was an improvement project aiming at increasing the solid waste collection and improvement of transportation and disposal system. Collection of MSW has been improved due to assistance of Govt. of Japan through Japan International Cooperation Agency (J1CA) also. They have provided 40 trucks and around 200 waste collection containers, 14 machines including excavators, bulldozers and compactors for the landfill site operations. These Projects have 
definitely improved collection component of solid waste management, but ultimate disposal of collected waste is still an issue to be resolved in engineering way. The implementation of SWEEP project will enhance community participation at basic level, generating additional source of income for low-paid communities through segregation at source [5].

\subsection{Disposal practices}

At present Rawalpindi Municipal Corporation does not have an appropriate landfill or waste disposal site. Presently open dumping, open burning and dumping of waste in un-engineered landfill sites is being practised. Hazardous waste, including industrial, chemical and hospital waste is not disposed of properly. Separation of toxic and non toxic waste is not done. This has severe health, safety and environmental impacts.

\subsection{Open dumping}

Open dumping of municipal solid waste is being carried out at various places where heaps of solid waste can be seen over the large area. Followings are the public health and ecological impacts being caused by the open dumping of solid waste in Rawalpindi city:

$\checkmark \quad$ Dust and Filthy Dirt: Strong wind and storm spread dust and filth to large area causing public health problems.

$\checkmark$ Odor: A large area of inhabitants is affected due to odor emitting from these dumps.

$\checkmark \quad$ Breeding Ground: Bacterial and virus are bred, causing epidemic diseases.

$\checkmark \quad$ Rats and other Vermin: Rats and other vermin find superior living conditions, with their attendants' fleas carrying bubonic plague.

$\checkmark$ Toxic Gases: Toxic gases are continuously released into the atmosphere.

$\checkmark \quad$ Leachate Contamination: Percolating rainwater through the open dump contaminating ground water resources.

$\checkmark \quad$ Health and Sanitation: Health and sanitation of the human beings living in the vicinity is seriously endangered.

$\checkmark \quad$ Surface Water Contamination: Liquid from dumps and unengineered landfills contaminates surface water sources.

\subsection{Open burning}

Often the solid waste collected at the communal bins is burnt mainly to reduce the volume, burning of waste in or around the bins is a sight of common occurrence creating tremendous air pollution. Open burning of accumulated solid waste results in the production of a variety of gaseous and particulate emission, many of which are thought to have serious health impacts. Open burning produces following solid residues also:

$\begin{array}{ll}1 & \text { Bottom ash } \\ 2 & \text { Fly ash }\end{array}$




\subsection{Suitability of disposal method for Rawalpindi city}

\subsubsection{Composting}

Rawalpindi city cannot have this facility of composting plant for the time being because of the following factors;

$\checkmark$ Underdeveloped market for compost: Composting is not a popular method of producing land conditioner, as farmers are relaying heavily on chemical fertilizer. Farmers are needed to be educated for the utility of compost as substitute for chemical fertilizer.

$\checkmark$ Huge quantity of waste: The processing of whole quantities from settlements and towns is not possible with this natural method completely. Huge quantities need engineered plants with respective technical layout and installations, considering the legal regulations for protection of people and environment.

$\checkmark$ Odor: The decomposing waste piles release an uncomfortable smell into the environment.

$\checkmark$ Expensive investment: Modern composting plants require a major capital investment.

$\checkmark$ Segregation of waste: Separation of non-compostable matter in the garbage is also problematic. This includes glass-fragments, stones, plastic, textiles rubber, bones, small metal pieces and other pollutant materials like batteries.

\subsubsection{Sanitary land-filling}

Some of the advantages of the sanitary land-filling method of disposal are as follows:-

$\checkmark \quad$ The initial investment is low compared with other disposal methods.

$\checkmark \quad$ A sanitary landfill is a complete or final disposal method as compared to incineration or composting which require additional treatment or disposal operation for residue, quenching water, and non compostable material etc.

$\checkmark \quad$ A sanitary landfill can receive all types of solid waste, eliminating the necessity of separate collection.

$\checkmark$ Sanitary landfill is flexible method. Increased quantities of solid waste can be disposed of with little additional personnel and equipment.

$\checkmark \quad$ Sub marginal land can be reclaimed for use as parking lots, playgrounds, golf courses, and even airports.

$\checkmark$ Sanitary landfill is the most cost-effective system of solid waste disposal for most urban areas in developing countries. Composting of solid waste costs 2-3 times more than sanitary landfill, and incineration costs 5-10 times more [6].

\section{Conclusions}

All major cities of Pakistan lack safe disposal practices and do not have any properly designed and operational facility for waste disposal. At present solid waste is dumped openly along roadsides, any available ravines or depressions. 
Like all cities of Pakistan Rawalpindi city also does not have any integrated approach for solid waste management. Municipal solid waste is being thrown in the open drains, open spaces and around the street corners and partially open burnt which results in aesthetically bad look, outbreak of diseases and environmental pollution. Waste collection system is quite inadequate as it collects only $80 \%$ of the total waste generated. Collection of waste is limited to influential areas. Poor community areas are mostly ignored and the collection efficiency is very low. As a result solid waste remains scattered throughout the remaining areas. Number of containers, collection bins and collection vehicles are too less in comparison with urban population and quantity of generated waste. There is no proper management of hazardous waste, hazardous hospital and industrial wastes are being simply treated as ordinary waste. As per present practice, solid waste is finally disposed in un-engineered way i.e. waste is dumped in low lying areas/depressions or excavated trenches and buried by soil cover on the top without taking care of leachate collection and management of landfill gases (produced by the decomposition of wastes) which ultimately deteriorates the quality of underground water and air pollution by firing of landfill gases.

\section{References}

[1] Engineering Planning and Management Consultant, "Data collection of national study on privatization of solid waste management in eight cities of Pakistan" 1996

[2] George Tchobanoglous, Hilary Theisen, and Samuel A. Vigil, "Integrated Solid Waste Management" McGraw Hill edition.

[3] Davis \& Cornwell, "Introduction to Environmental Engineering" Second Edition, McGraw Hill

[4] Akio, "Domestic Solid Waste Management in Pakistan" Japan International Corporation Agency (JICA), Pakistan, 2002.

[5] An Introduction to Rawalpindi Municipal Corporation". Rawalpindi Municipal Corporation, 1997.

[6] Guidance Published in May 1996 by the World Bank as an Urban Infrastructure Note, updated in November 2004 